\title{
TITLE:
}

\section{A rat model of glaucoma induced by episcleral vein ligation( Abstract_要旨)}

$\operatorname{AUTHOR}(S)$ :

Yu, Saiyuu

\section{CITATION:}

Yu, Saiyuu. A rat model of glaucoma induced by episcleral vein ligation. 京都大学, 2006, 博士(医学)

\section{ISSUE DATE:}

2006-11-24

URL:

http://hdl.handle.net/2433/135639

RIGHT: 


\begin{tabular}{|c|c|}
\hline 名 & $\begin{array}{ll}\text { 甹 } & \text { サ1 } \\
\text { 湯 } & \text { 才 }\end{array}$ \\
\hline 学位 (専攻分野) & 博 士 (医 学) \\
\hline 学位 記 番号 & 医 博 第 3019 号 \\
\hline 学位授与の日付 & 平成 18 年 11 月 24 日 \\
\hline 学位授与の要件 & 学位規則第 4 条第 1 項該当 \\
\hline 研究科・専攻 & 医学研究科外科系専攻 \\
\hline 学位論文題目 & $\begin{array}{l}\text { A Rat Model of Glaucoma Induced by Episcleral Vein Ligation } \\
\text { (上強膜静脈結紮により作成された緑内障モデルラット) }\end{array}$ \\
\hline
\end{tabular}

\section{論文 内容の 要旨}

緑内障は失明原因の上位を占めており, その病態は進行性の網膜神経節細胞死および視神経乳頭の陥凹拡大のある視神経 症と定義されている。眼圧上昇は緑内障性視神経症に対するもっとも重要なりスクファクターのひとつであるとされて抢り， 緑内障の病態解明のために眼圧上昇させたさまざまな動物モデルが作成され, いかに網膜神経節細胞死が進行していくのか, またその治療方法などが模索されている。動物モデルとして，サル，ラット，マウスなどが用いられているが，扱いやすさ， コスト面からもラットが使用されることが多い。ラットには，高調食塩水を上強膜静脈から投与するもの，レーザーを使用 し隅角を障害させるもの，上強膜静脈を閉塞させるものなどで眼圧を上昇させる緑内障モデルが今までに報告されているが， 眼圧上昇の程度や期間が報告によってさまざまである。今回, 長期間の眼圧上昇可能であった緑内障モデルを作成し, 網膜 神経節細胞死を含めた形態の変化について検討を行った。

モデル作成方法としてラットの上強膜静脈をナイロン糸によって結紮し閉塞させた。それにより，前房水の流出阻害を行 い眼圧上昇させる目的である。処置後, 定期的に眼圧測定した結果処置翌日から約 7 ケ月間の継続的な眼圧上昇が可能であ つた。眼圧上昇による形態学的変化は過去の報告通り，網膜神経節細胞の脱落と視神経乳頭の陥凹拡大を認めた。また網膜 神経節細胞死の程度は，6ヶ月間で約35\%の減少であった。これらの減少が Apoptosis であることは TUNEL 法にて確認 を行った。免疫染色では, 網膜神経節細胞のマーカーである p $75 ・ B r n 3 b$, Müller 細胞のマーカーである p $27 \mathrm{kip} 1$ の変化を 認めたがその他のマーカー（bipolar 細胞, Amacrine 細胞, Horizontal 細胞, Photoreceptor) では変化を認めなかった。 さらに高眼圧状態での神経栄養因子の発現について検討を行ったところ, 最終的に, fibroblast growth factor, basic (bFGF) と ciliary neurotrophic factor (CNTF) の発現の低下を認めたが, brain derived neurotrophic factor と glial derived neurotrophic factorの発現に変化は認めなかった。

今回作成した緑内障モデルは，処置後長期間の眼圧上昇が可能であり，ヒトにおける緑内障の形態変化とよく似た変化を 示した。網膜の変化として網膜神経節細胞の減少以外に Müller 細胞の变化を認めたが, Müller 細胞は眼圧上昇初期に脱分 化・増殖し，その後徐々にそれらが低下することが報告されている。今回の解析の結果では, Müller 細胞の分裂のマーカ 一である $\mathrm{p} 27 \mathrm{kip} 1$ が最終的に変化していた。これらから，眼圧上昇による影響が Müller 細胞の脱分化・増殖（分裂）に影 響しているものと考えられた。神経栄養因子についてはさまざまな投与方法により，網膜神経節細胞死から保護することが 可能であることが報告されているが，緑内障による長期的な発現の変化はあまり知られていない。今回，緑内障モデルラッ トにて神経栄養因子の発現の変化について検討を行い，その結果，CNTFとbFGF の発現低下を認めた。今後これらの 2 つの神経栄養因子の投与が緑内障における網膜神経節細胞死の抑制につながる可能性が示唆された。今後作成したモデルを さらに緑内障性視神経症の分子細胞学的解析や緑内障治療のために役立てていきたいと考える。 
緑内障の解析は, 神経細胞死のメカニズムの理解や視野の改善を含めた新たな緑内障治療のために非常に重要である。そ のため，確立された慢性の緑内障モデルラットの作成は必要であると考えられる。今回長期的に眼圧負荷が可能であり，そ の組織学的変化はヒトの緑内障性変化と類似していた緑内障モデルラットの作成が可能であったことが確認された。組織学 的変化の特徴として，網膜神経節細胞の減少は過去の報告同様であるが，神経伝達物質などに影響を与える Müller 細胞の 減少も認められた。また Müller 細胞は，神経栄養因子の作用の一部にも間接的に影響することが知られている。そのため， 神経栄養因子の発現を慢性期で調べた結果，CNTFと bFGF で減少することが判明した。そのような神経栄養因子の眼圧 負荷による減少は，今後の緑内障の神経保護における治療につながるものと期待される。さらに，緑内障眼における骨髄間 葉系幹細胞の移植を行ったところ，網膜の神経線維層及び網膜神経節細胞層への生着を確認したが，神経細胞への分化を確 認するには至らなかった。しかし，移植された骨髄間葉系幹細胞から数種類の神経栄養因子の発現が確認された。その結果， 眼圧負荷による網膜神経節細胞の細胞死が抑制された。以上の結果は，今後新たな緑内障治療の可能性が示唆されたものと 思われる。以上の研究は緑内障の病態の解明に貢献し今後の緑内障治療に寄与するところが多い。

したがって，本論文は博士 (医学) の学位論文として価值のあるものと認める。

なお，本学位授与申請者は，平成18年 6 月 20 日実施の論文内容とそれに関連した試問を受け，合格と認められたものであ る。 